\title{
АКТУАЛЬНІ ПРОБЛЕМИ ПРАВОВОГО РЕГУЛЮВАННЯ НАЦІОНАЛЬНОӤ БЕЗПЕКИ УКРАЇНИ У СФЕРІ МОРСЬКОї ДІЯЛЬНОСТІ І ШЛЯХИ ЇХ ВИРІІІЕННЯ
}

\author{
УСТИМЕНКО Богдан Миколайович - аспірант Національного педагогічного \\ університету імені М.П. Драгоманова, адвокат (Київ, Україна) \\ ORCID ID: 0000-0001-9151-9438 \\ УДК 342.1 \\ DOI 10.32782/LAW.UA.2021.2.13
}

\begin{abstract}
У статті проведений юридичний аналіз деяких міжнародних договорів та нормативноправових актів України, що мають значення для правого регулювання національної безпеки України у сбері морсъкої діяльності. Також автор статті наводить власне визначення терміна «національна безпека України у сфері морсъкої діяльності». Окрему увагу приділено основним прогалинам у правовому регулюванні національної безпеки України у сбері морськоі діяльності. За результатами проведеного дослідження були зроблені, серед інших, висновки щодо необхідності усунення виявлених прогалин у праві шляхом прийняття Верховною Радою України закону України про внутрішні води та територіальне море Украӥни із визначенням координат серединної ліній, а також затвердження Указом Президента україни Стратегї морської безпеки України.

Ключові слова: правове регулювання, національна безпека України у сбері морсъкої діяльності, морсъка безпека України, морсъка діяльність, закон про внутрішні води та територіальне море України, Стратегія морсъкой безпеки України, Чорне море, Азовсъке море, Керченсъка протока.
\end{abstract}

Вважаємо за необхідне почати це дослідження 3 тлумачення поняття «правове регулювання».

Так, правове регулювання (від лат. regulare - спрямовувати, впорядковувати) - це один із основних засобів державного впливу на суспільні відносини з метою їх упорядкування в інтересах людини, суспільства і дер- жави. E різновидом соціального регулювання. Предмет правового регулювання - правові, політичні, економічні та інші суспільні відносини, впорядкування яких неможливе без використання норм права. Правове регулювання забезпечується за допомогою спеціально створеного державою механізму. Головними складовими елементами цього механізму є: а) норми права, зафіксовані в законах та інших правових актах, якими визначається модель можливої та необхідної поведінки суб'єктів суспільних відносин (норми права - основа механізму правового регулювання); б) юридичні факти, тобто конкретні життєві обставини, 3 якими пов'язані виникнення, зміна чи припинення правових відносин; в) власне правові відносини, тобто суспільні відносини, опосередковані нормами права; г) акти реалізації прав та обов'язків суб'єктів суспільних відносин, тобто дії цих суб'єктів у межах приписів відповідних правових норм; г) правові санкції щодо порушників норм права. Правове регулювання в Україні забезпечується системою державних органів законодавчої, виконавчої та судової гілок влади, прокуратурою та іншими контролюючими органами. Цей процес також зумовлений рівнем правосвідомості й правової культури громадян [1, с. 692].

Аналогічне тлумачення поняття «правове регулювання» містить Юридична енциклопедія [2, с. 40 - 41].

У свою чергу, під правовим регулюванням суспільних відносин ми розуміємо лише одну з форм впливу права на суспільні відно- 
сини - вплив за допомогою специфічних правових засобів: норм права, правовідносин, актів реалізації [3, с. 436].

Також у контексті цього дослідження, необхідно дати тлумачення наступним поняттям: «національна безпека», «морська діяльність» та «національна безпека України у сфері морської діяльності».

Відповідно до пункту 9 частини першої статті 1 Закону України «Про національну безпеку України» національна безпека України - це захищеність державного суверенітету, територіальної цілісності, демократичного конституційного ладу та інших національних інтересів України від реальних та потенційних загроз [4].

Згідно із Морською доктриною України до 2035 року морська діяльність - це діяльність у сфері забезпечення сталого економічного і соціального розвитку суспільства, вивчення, освоєння і використання моря, захисту національної безпеки, морська торгівля (комерційні операції, які пов’язані 3 використанням морських суден, купівляпродаж товарів, що перевозяться морським шляхом, фрахтування суден, морське агентування, морське страхування тощо). Складовими морської діяльності є: торговельне мореплавство, морський транспорт, суднобудування, військово-морська діяльність, використання водних біоресурсів та інших ресурсів моря, туристична та рекреаційна діяльність, а також діяльність у сферах науки, освіти, екології і захисту моря [5].

Водночас, чинне законодавство України не містить термінів «національна безпека України у сфері морської діяльності» або «морська безпека України», які є тотожними, а також визначення цих термінів.

Враховуючи згадану вище суттєву прогалину в українському праві та проаналізувавши Закон України «Про національну безпеку України» [4], Стратегію національної безпеки України [6], Морську доктрину України до 2035 року [5], Довідник під назвою «Реформування Сектору Морської Безпеки», прийнятий органами державної влади США [7], Доповідь Генерального Секретаря Організації Об’єднаних Націй «Світовий океан та морське право» [8], а також розглянувши поняття «морська безпека», яке сформульоване всесвітньо відомими у галузі морського права вченими Наталі Клайн (Natalie Klein), Джоани Моссоп (Joanna Mossop) та Дональда Ротвелла (Donald R. Rothwell) [9], автор цього дослідження самостійно визначив термін «національна безпека України у сфері морської діяльності».

Так, національна безпека України у сфері морської діяльності - це захищеність національних інтересів України на морі від реальних та потенційних загроз, а також забезпечення сталого розвитку України як морської держави.

Тобто є очевидним, що забезпечення національної безпеки України у сфері морської діяльності без іiі правового регулювання неможливе.

Чинне законодавство України містить чисельні нормативно-правові акти, у тому числі підзаконні, за допомогою яких здійснюється правове регулювання національної безпеки України у сфері морської діяльності, а саме: Конституцію України, Закон України «Про міжнародні договори України», Закон України «Про національну безпеку України», Закон України «Про державний кордон України», Закон України «Про засади внутрішньої і зовнішньої політики», Закон України «Про оборону України», Закон України «Про державну таємницю», Закон України «Про розвідку», Закон України «Про правовий режим воєнного стану», Закон України «Про оперативно-розшукову діяльність», Закон України «Про контррозвідувальну діяльність», Закон України «Про боротьбу з тероризмом», Закон України «Про організаційно-правові основи боротьби з організованою злочинністю», Закон України «Про основні засади забезпечення кібербезпеки України», Закон України «Про освіту», Закон України «Про наукову і науково-технічну діяльність», Закон України «Про охорону навколишнього природного середовища», Закон України «Про рибне господарство, промислове рибальство та охорону водних біоресурсів», Закон України «Про транспорт», Закон України «Про морські порти України», Закон України «Про Раду національної безпеки і оборони України», Закон України «Про Збройні Сили України», Закон України «Про Службу зовнішньої розвідки України», Закон України «Про Служ- 


\section{Адміністративне право}

бу безпеки України», Закон України «Про Кабінет Міністрів України», Закон України «Про центральні органи виконавчої влади», «Про громадські об'єднання», Закон України «Про прокуратуру», Закон України «Про Національну поліцію», Закон України «Про Національну гвардію України», Закон України «Про Державну прикордонну службу України», Закон України «Про державну спеціальну службу транспорту», Закон України «Про Державну службу спеціального зв’язку та захисту інформації України», Закон України «Про прилеглу зону України», Закон України «Про виключну (морську) економічну зону України», Кодекс торговельного мореплавства України, Водний кодекс України, Кримінальний кодекс України, Цивільний кодекс України, Господарський кодекс України, Кодекс України про адміністративні правопорушення, Митний кодекс України, Бюджетний кодекс України, Кодекс України про надра, Кодекс цивільного захисту України, Стратегію національної безпеки України, затверджену Указом Президента України від 14.09.2020 р. № 392/2020, Стратегію воєнної безпеки України, затверджену Указом Президента України від 25.03.2021 р.№ 121/2021, Морську доктрину України на період до 2035 року, затверджену постановою Кабінету Міністрів України від 07.10.2009 p. № 1307 , Положення про порядок охорони суверенних прав України у її виключній (морській) економічній зоні, затверджене постановою Кабінету Міністрів України від 12.06.1996 р. № 642 тощо.

Наведений перелік законів та інших нормативно-правових актів не 6 вичерпним.

Окрім цього, частиною національного законодавства, яке регулює національну безпеку України у сфері морської діяльності, є наступні міжнародні договори: Статут Організації Об'єднаних Націй, Конвенція Організації Об'єднаних Націй з морського права, Меморандум про гарантії безпеки у зв'язку з приєднанням України до Договору про нерозповсюдження ядерної зброї, Конвенція про режим проток, Конвенція про режим судноплавства на Дунаї, Конвенція про територіальне море та прилеглу зону, Конвенція про відкрите море, Конвенція про континентальний шельф, Міжнародна конвенція 3 охорони людського життя на морі 1974 року, Міжнародна конвенція про пошук і рятування на морі 1979 року, Міжнародна конвенція про підготовку і дипломування моряків та несення вахти 1978 року, Міжнародна конвенція про стандарти підготовки, сертифікації персоналу риболовних суден та несення вахти 1995 року, Міжнародний кодекс з охорони суден та портових засобів, Міжнародна конвенція по запобіганню забрудненню 3 суден 1973 року, Конвенція про боротьбу з незаконними актами, спрямованими проти безпеки морського судноплавства, Конвенція про міжнародну організацію морського супутникового зв'язку (IНMAРСАТ), Договір про принципи діяльності держав по дослідженню і використанню космічного простору, включаючи Місяць та інші небесні тіла, Конвенція про захист Чорного моря від забруднення.

Цей перелік міжнародних договорів України також не є вичерпним.

Aле не зважаючись на все різноманіття згаданих міжнародних договорів, законів, кодексів та інших нормативно-правових актів України, існують суттєві недоліки нормотворчої діяльності, пов'язані 3 нормативно-правовою регламентацією національної безпеки України у сфері морської діяльності (морської безпеки України), як групи суспільних відносин.

Так, Конвенцією Організації Об'єднаних націй з морського права визначені, у тому числі, наступні морські простори прибережної держави: внутрішні води, територіальне море, прилегла зона та виключна економічна зона [10].

Верховна Рада України, враховуючи відповідні положення Конвенції ООН з морського права та з метою визначення правового режиму виключної (морської) економічної зони України, прийняла Закон України «Про виключну (морську) економічну зону України» [11].

12 жовтня 2018 року Рада національної безпеки і оборони України ухвалила рішення «Про невідкладні заходи щодо захисту національних інтересів на Півдні та Сході України, у Чорному та Азовському морях і Керченській протоці, що введене в дію Указом Президента України [12]. Цим рішен- 
ням, серед іншого, було зобов'язано Кабінет Міністрів України ухвалити у місячний строк рішення щодо внесення до Верховної Ради України проєктів законів України про внутрішні води, територіальне море та прилеглу зону України із визначенням координат серединної лінії.

6 грудня 2018 року Верховна Рада України прийняла Закон України «Про прилеглу зону України», яким встановлено статус та визначено правовий режим прилеглої зони України, а також порядок реалізації Україною в цій зоні своїх прав як прибережної держави відповідно до Конвенції ООН 3 морського права, інших міжнародних договорів України, загальновизнаних норм i принципів міжнародного права, Конституції та законів України [13].

Разом з тим, закони України про внутрішні води та територіальне море Верховною Радою України не прийняті, координати серединної лінії не визначені та, відповідно, порядок реалізації Україною в цих морських просторах повноти своїх прав як прибережної держави станом на липень 2021 року не встановлений.

Слід додати, що Закон України «Про Державний кордон України» містить приписи, що стосуються як внутрішніх вод, так і територіального моря України, але переважно лише в контексті режиму та охорони державного кордону України [14]. Цей закон не містить повноцінного порядку реалізації Україною, як прибережною державою, своїх прав у цих морських просторах, а також не встановлює координати серединної лінії в українських морських просторах.

Вбачаємо за слушне зазначити, що багато прибережних держав у світи прийняли власні спеціальні закони про морські простори, зокрема, внутрішні води та територіальне море. Наведемо лише декілька прикладів. Спеціальні закони про морські простори прийняті в Канаді (An Act respecting the oceans of Canada, 18 December 1996) [15], Російській Федерації (Федеральний Закон «О внутренних морских водах, территориальном море и прилежащей зоне Российской Федерации» [16], Федеральний Закон «Об исключительной экономической зоне Российской Федерации» [17], Федеральний Закон «О конти- нентальном шельфе Российской Федерации» [18]), Китайській Народній Республіці (Law on the Territorial Sea and the Contiguous Zone of 25 February 1992 [19], Exclusive Economic Zone and Continental Shelf Act) [20], Сполученому Королівстві Великої Британії та Північної Ірландії (Territorial Waters Jurisdiction Act, 1878 [21], Territorial Sea Act 1987 [22] та інші), Румуніï (Act concerning the Legal Regime of the Internal Waters, the Territorial Sea and the Contiguous Zone of Romania, 7 August 1990) [23] та інших прибережних державах.

Отже, вважаємо, що Верховній Раді України необхідно прийняти єдиний закон України про внутрішні води та територіальне море України із визначенням координат серединної лінії, який буде мати колосальне комплексне значення для законодавчого врегулювання питань національної безпеки і оборони.

Ще однією актуальною проблемою правового регулювання національної безпеки України у сфері морської діяльності є відсутність Стратегії морської безпеки України.

У контексті цієї прогалини права слід звернути увагу на приписи Закону України «Про національну безпеку України» та Стратегію національної безпеки України.

Так, Закон України «Про національну безпеку України» відповідно до статей 1, 2, 17, 19 і 92 Конституції України визначає основи та принципи національної безпеки i оборони, цілі та основні засади державної політики, що гарантуватимуть суспільству і кожному громадянину захист від загроз.

Відповідно до пункту 15 частини першої статті 1 Закону України «Про національну безпеку України» планування у сфері національної безпеки - це функція державного управління 3 визначення пріоритетів, завдань і заходів із забезпечення національної безпеки України, збалансованого розвитку складових сектору безпеки і оборони на основі оцінки безпекової обстановки та 3 урахуванням фінансово-економічних можливостей держави [4].

Метою планування у сферах національної безпеки і оборони є забезпечення реалізації державної політики у цих сферах шляхом розроблення стратегій, концепцій, програм, планів розвитку органів сектору безпеки i 


\section{Адміністративне право}

оборони, управління ресурсами та ефективного їх розподілу (частина перша статті 25 Закону України «Про національну безпеку України»).

Приписом пункту 19 частини першої статті 1 Закону України «Про національну безпеку України» встановлено, що Стратегія національної безпеки України - це документ, що визначає актуальні загрози національній безпеці України та відповідні цілі, завдання, механізми захисту національних інтересів України та є основою для планування і реалізації державної політики у сфері національної безпеки.

Окрім цього, Стратегія національної безпеки України є основним документом довгострокового планування, яким визначаються основні напрями державної політики у сфері національної безпеки (частина перша статті 26 Закону України «Про національну безпеку України»).

Згідно із частиною третьою статті 26 Закону України «Про національну безпеку України» Стратегія національної безпеки України є основою для підготовки всіх інших документів щодо планування у сферах національної безпеки і оборони.

Також загрози національній безпеці України та відповідні пріоритети державної політики у сферах національної безпеки i оборони визначаються у Стратегії національної безпеки України, Стратегії воєнної безпеки України, Стратегії кібербезпеки України, інших документах з питань національної безпеки і оборони, які схвалюються Радою національної безпеки і оборони України і затверджуються указами Президента України (частина п’ята статті 3 Закону України «Про національну безпеку України»).

Пунктом 4 частини першої статті 13 Закону України «Про національну безпеку України» встановлено, що керівництво у сферах національної безпеки і оборони відповідно до Конституції України здійснює Президент України, який, серед іншого, видає укази і розпорядження 3 питань національної безпеки і оборони, що є обов'язковими до виконання на території України, зокрема, указами Президента України затверджуються Стратегія національної безпеки України, Стратегія воєнної безпеки України, інші стратегії, доктрини, концепції, якими визначаються актуальні загрози національній безпеці, основні напрями і завдання державної політики у сферах національної безпеки і оборони, розвитку сектору безпеки і оборони.

Президент України у разі необхідності може вносити зміни до Стратегії національної безпеки України в установленому порядку на підставі частини першої статті 26 Закону України «Про національну безпеку України».

Пунктом 55 Стратегії національної безпеки України встановлено, що Україна морська і річкова держава. Для реалізації іï потенціалу будемо захищати свободу судноплавства, сприяти ефективному використанню ресурсів Чорного та Азовського морів, річок Дніпра і Дунаю, розвивати торговельний флот і Військово-Морські Сили Збройних Сил України.

У пункті 17 Стратегії національної безпеки України також зазначено, що зберігається загроза з боку Російської Федерації вільному судноплавству у Чорному та Азовському морях, Керченській протоці.

У свою чергу, відповідно до пункту 66 Стратегії національної безпеки України ця Стратегія є основою для розроблення таких документів щодо планування у сферах національної безпеки і оборони, які визначатимуть шляхи та інструменти їі реалізації, а cаме:

Стратегія людського розвитку;

Стратегія воєнної безпеки України;

Стратегія громадської безпеки та цивільного захисту України;

Стратегія розвитку оборонно-промислового комплексу України;

Стратегія економічної безпеки;

Стратегія енергетичної безпеки;

Стратегія екологічної безпеки та адаптації до зміни клімату;

Стратегія біобезпеки та біологічного захисту;

Стратегія інформаційної безпеки;

Стратегія кібербезпеки України;

Стратегія зовнішньополітичної діяльності;

Стратегія забезпечення державної безпеки; 
Стратегія інтегрованого управління кордонами;

Стратегія продовольчої безпеки;

Національна розвідувальна програма.

Водночас, не зважаючи на ту обставину, що Україна є морською та річковою державою, вищезазначений перелік не містить документа під назвою «Стратегія морської безпеки України».

Вважаємо, що Стратегію морської безпеки України необхідно розробити та прийняти вже у поточному 2021 році, оскільки без цього документу якісного рівня правового регулювання національної безпеки України у сфері морської діяльності буде досягнути неможливо.

У Стратегії морської безпеки України слід визначити загрози національній безпеці у сфері морської діяльності та шляхи досягнення цілей і реалізації пріоритетів державної політики у цій сфері, зокрема: безпекове середовище (глобальні, регіональні та національні аспекти) у контексті морської безпеки; цілі, пріоритети та завдання державної політики у сфері морської діяльності; шляхи досягнення цілей державної політики у сфері морської діяльності; державні програми, галузеві стратегії та програми, які мають бути спрямовані на реалізацію Стратегії морської безпеки України, їхні цілі, відповідальних за розроблення документів, моніторинг їх виконання та оцінки.

Отже, національна безпека України у галузі морської діяльності як певна група суспільних відносин фактично існує, але іï нормативно-правова регламентація частково відсутня внаслідок недоліків нормотворчої діяльності.

3 огляду на все викладене вище, вважаємо за потрібне усунити зазначені прогалини у праві шляхом:

1) Прийняття Верховною Радою України закону України про внутрішні води та територіальне море України із визначенням координат серединної лінії;

2) Внесення змін Указом Президента України до пункту 66 Стратегії національної безпеки України, яким визначено перелік документів щодо планування у сферах національної безпеки і оборони. Додати до цього переліку документ під назвою «Стратегія морської безпеки України»;
3) Затвердження Указом Президента України Стратегії морської безпеки України;

4) Прийняття іншими органами державної влади нормативно-правових актів, необхідних для реалізації Стратегії морської безпеки України, та привести всі нормативно-правові акти у відповідність із Стратегією морської безпеки України.

\section{Література}

1. Великий енциклопедичний юридичний словник. Київ: «Юридична думка», 2007. $990 \mathrm{c}$.

2. Юридична енциклопедія. Том 5. Київ: «Українська енциклопедія» імені М.П. Бажана, 2003. 733 с.

3. Общая теория государства и права. Академический курс в 2-х томах. Том 2. Теория права. Москва: «Зерцало», 1998. 620 с.

4. Про національну безпеку України: Закон України від 21.06.2018 р. № 2469-VIII. URL: https://zakon.rada.gov.ua/laws/show/246919\#Text.

5. Морська доктрина України на період до 2035 року: постанова Кабінету Міністрів України від 07.10.2009 р. № 1307. URL: https://zakon.rada.gov.ua/laws/show/1307-2009$\underline{\text { п Text. }}$

6. Стратегія національної безпеки України: Указ Президента України від 14.09.2020 p. № 392/2020. URL: https://www.president. gov.ua/documents/3922020-35037.

7. The Maritime Security Sector Reform (MSSR) Guide of December 2010. URL:

https://www.usaid.gov/sites/default/files/ documents/1866/Maritime-Security-SectorReform_FINAL.pdf.

8. UN Secretary General, Oceans and the Law of the Sea: Report of the Secretary-General to the General Assembly, UN Doc A/63/63 of 10 March 2008. URL: https://documents-dds-ny.un.org/ doc/UNDOC/GEN/N08/266/26/PDF/N0826626. pdf?OpenElement.

9. Klein, N.; Mossop, J.; and Donald,R. Rothwell, «Australia, New Zealand and Maritime Security» in N. Klein, J. Mossop, andD.R. Rothwell (eds), Maritime Security: International Law and Policy Perspectives from Australia and New Zealand (Routledge Oxford 2010). 304 p.

10. United Nations Convention on the Law of the Sea of 10 December 1982. URL: $\underline{\text { https:// }}$ 


\section{Адміністративне право}

www.un.org/depts/los/convention_agreements/ texts/unclos/unclos_e.pdf.

11. Про виключну (морську) економічну зону України: Закон України від 16.05.1995 р. № 162/95-BP. URL: https://zakon.rada.gov.ua/ laws/show/162/95-вр\#Text.

12. Про рішення Ради національної безпеки і оборони України від 12 жовтня 2018 року «Про невідкладні заходи щодо захисту національних інтересів на Півдні та Сході України, у Чорному та Азовському морях і Керченській протоці»: Указ Президента України від 12.10.2018 № 320/2018. URL: https://www. president.gov.ua/documents/3202018-25174.

13. Про прилеглу зону України: Закон України від 06.12.2018 р. № 2641-VIII. URL: https://zakon.rada.gov.ua/laws/show/264119\#Text.

14. Про Державний кордон України: Закон України від 04.11.1991 р. № 1777-XII. URL: https://zakon.rada.gov.ua/laws/show/177712\#Text.

15. An Act respecting the oceans of Canada, 18 December 1996. URL: https://www.un.org/ Depts/los/LEGISLATIONANDTREATIES/ PDFFILES/CAN_1996_Act.pdf.

16. О внутренних морских водах, территориальном море и прилежащей зоне Российской Федерации: Федеральный Закон от 31.07.1998 г. № 155-Ф3. URL: http://pravo. gov.ru/proxy/ips/?docbody $=$ \&nd $=102054703$.

17. Об исключительной экономической зоне Российской Федерации: Федеральный Закон от 17.12.1998 г.№ 191-Ф3. URL: http://pravo.gov.ru/proxy/ ips/?docbody $=$ \&nd $=102057097$.

18. О континентальном шельфе Российской Федерации: Федеральный Закон от 30.11 .1995 г. № 187-Ф3. URL: http://pravo. gov.ru/proxy/ips/?docbody $=$ \&nd $=102038488$.

19. The Law on the Territorial Sea and the Contiguous Zone of the People's Republic of China, adopted at the 24th meeting of the Standing Committee of the National People's Congress on 25 February 1992. URL: https://www.un.org/ depts/los/LEGISLATIONANDTREATIES/PDFFILES/CHN 1992 Law.pdf.

20. Exclusive Economic Zone and Continental Shelf Act, adopted at at the third session of the Standing Committee of the Ninth National People's Congress, 26 June 1998. URL:
https://www.un.org/Depts/los/LEGISLATIONANDTREATIES/PDFFILES/chn_1998_eez_act. pdf.

21. Territorial Waters Jurisdiction Act, 1878 of the United Kingdom of Great Britain and Northern Ireland. URL: https://www.un.org/ Depts/los/LEGISLATIONANDTREATIES/ PDFFILES/GBR 1878 Act.pdf.

22. Territorial Sea Act 1987 of the United Kingdom of Great Britain and Northern Ireland. URL: https://www.un.org/depts/los/ LEGISLATIONANDTREATIES/PDFFILES/ GBR_1987_Act.pdf.

23. Act concerning the Legal Regime of the Internal Waters, the Territorial Sea and the Contiguous Zone of Romania, 7 August 1990. URL: https://www.un.org/Depts/los/LEGISLATIONANDTREATIES/PDFFILES/ROM_1990_Act.pdf.

Ustymenko Bohdan - PhD candidate of $\mathrm{Na}$ tional Pedagogical Dragomanov University, attorneyat-law (Kyiz, Ukraine)

ORCID ID: 0000-0001-9151-9438

Email: b.ustymenko@protonmail.ch

WAYS TO ADDRESS TOPICAL ISSUES OF LEGAL REGULATIION OF NATIONAL SECURITY OF UKRAINE WITHIN THE SPHERE OF MARITIME ACTIVITIES

The article provides a legal analysis of some international treaties and legislation of Ukraine that are important for the legal regulation of national security of Ukraine within the sphere of maritime activities. Also, the author of the article gives his own definition of the term "national security of Ukraine within the sphere of maritime activities." Special attention is paid to the main gaps in the legal regulation of national security of Ukraine within the sphere of maritime activities. The author makes a conclusion that it is necessary for Ukraine to adopt the Law on Internal Waters and Territorial Sea of Ukraine with the median line and approve the Maritime Security Strategy of Ukraine.

Key words: legal regulation, national security of Ukraine within the sphere of maritime activities, maritime security of Ukraine, maritime activities, Law on Internal Waters and Territorial Sea of Ukraine, Maritime Security Strategy of Ukraine, the Black Sea, the Sea of Azov, the Kerch Strait. 